\title{
Yeni Toplumsal Hareketlerin Sınıf Dinamiği: Türkiye LGBT Hareketi
}

Barış ERDOĞAN* Esra KÖTEN**

\section{Özet}

1960’lı yıllardan itibaren dünya “yeni” konular, talepler, sınıflar, katılımcılar ve örgütlenme yapıları içeren "yeni” toplumsal hareketlere sahne olmaya başlamıştır. Bu hareketler "eski” hareketlerden birçok yönüyle farklılıklar taşımakla birlikte, devamlılıklar da arz etmektedir. Eski toplumsal hareketlerin büyük meseleleri içinde çoğu kez önemsiz ya da ikincil görülen ve eski örgüt yapıları içine kıstırılan çeşitli konu ve talepler, yeni toplumsal hareketlerin odağı olmuştur. Bu çerçevede, geleneksel tanımıyla sınıf görünürlügünü yitirmeye başlamış, bu durum sınıfın ortadan kalktığı ya da önemsizleştiği yanılgısına neden olmuştur. Ancak proleterleşmiş yeni orta sınıf, yeni toplumsal hareketlerin başlıca aktörü haline gelmiştir. Bu yeni orta sınıfın, doğrudan ve alışılagelmiş biçimde üretim ilişkileri ile ilgili taleplerini dile getirmek yerine, kimlik ve yaşam tarzı gibi sınıftan bağımsızmış gibi görünen konularda mücadeleler içeren yeni toplumsal hareketler içinde aktif hale geldiği görülmektedir. Bu kapsamda dünyada ve Türkiye'de gelişen toplumsal muhalefet içerikli hareketlerden biri de, merkezini kentli, eğitimli, yeni/proleterleşen orta sınıfın oluşturduğu LGBT hareketidir. Bu çalışmada, yeni toplumsal hareketler ve sınıf sorunuyla ilgili kuramsal yaklaşımların tartışılmasının ardından yeni toplumsal hareketler kapsamında Türkiye'de LGBT hareketine daha yakından bakmak amaçlanmaktadır.

Anahtar Kelimeler: Toplumsal hareketler, sınıf, LGBT

* Yrd. Doç. Dr. İstanbul Gelişim Üniversitesi, İktisadi İdari ve Sosyal Bilimler Fakültesi, Sosyoloji Bölümü. E-mail: bariserdogan74@gmail.com

** Yrd. Doç. Dr. İstanbul Gelişim Üniversitesi, İktisadi İdari ve Sosyal Bilimler Fakültesi, Sosyoloji Bölümü. E-mail: esrakoten@gmail.com 


\title{
The Class Dynamics of New Social Movements: LGBT Movement in Turkey
}

\begin{abstract}
Since the 1960s, the world has been the scene of "new" social movements that consist of "new" issues, demands, classes, participants and organizational structures. These movements differ in many respects from the "old" movements, but also share continuities with them. Various issues and demands that have mostly been seen as insignificant or secondary within the big issues of old social movements and clamped into the old organizational structures, have been the focus of new social movements. In this context, class has started to lose its visibility in its traditional definition, and this has led to the misconception that class has ceased to exist or has been trivialized. However, proletarianized new middle class has become the main actor of the new social movements. This new middle class is becoming active in new social movements that contain struggles on issues such as identity and life style that appear to be independent of class, rather than making demands about the relations of production directly and in a usual way. Accordingly, one of the social opposition movements has developed throughout the world -and in Turkey- is the LGBT movement which entails the urbanized, educated, new/proletarianised middle class at the center. After discussing theoretical approaches on new social movements and class problem, this study aims to look more closely into the LGBT movement in Turkey in the scope of new social movements.
\end{abstract}

Keywords: Social movements, class, LGBT

\section{Yeni Toplumsal Hareketler ve Sınıf Tartışmaları}

Toplumsal hareketleri, sosyal bir sorunu çözmek, toplumda meydana gelen bir değişimi desteklemek ya da engellemek amacıyla belli bir grup tarafından yürütülen örgütlü kolektif faaliyetler olarak tanımlamak mümkündür. Toplumsal hareketleri öne çıkaran faktör ise sanayileşme ve onun yarattığı toplumsal dönüşümler ve gerilimler karşısında oluşan yeni duruma karşı toplumsal dinamiklerin farklı/karşıt reaksiyonlarıdır. Kimi kuramcılar (Pakulski, 1993b; Offe, 1987) sanayi devriminden 1960'lara kadar geçen süre içinde yer alan ve merkezinde ekonomik eşitlikçi hak talepleri bulunan sosyal hareketleri “eski” toplumsal hareketler; bu tarihten sonra ortaya çıkan ve etnisite-1rk-cinsiyet gibi farklılıklarından kaynaklanan sosyal sorunları ve talepleri dile getiren sosyal hareketleri ise "yeni" toplumsal hareketler olarak adlandırmaktadırlar. "Eski”nin aktörleri genellikle "işçi sınıfı"nın üyeleri olarak tanımlanırken, "yeni” toplumsal hareketlerin aktörleri Bourdieucü bir ifadeyle sosyal/kültürel/simgesel sermayeleri nedeniyle farklı bir habitus evreninde var olan ve etnik, kültürel, dini ve cinsel kimliklerine vurgu yapılan “orta/üst sinıflara” mensup bireyler olarak görülmektedirler.

Genel olarak yeni toplumsal hareketlerin dünyada 1960'ların sonlarından itibaren küreselleşme, postmodernleşme ve post-endüstriyelleşmeye paralel olarak ortaya çıktığı ve katılımcıları ve 
amaçları itibariyle eski toplumsal hareketlerden ayrışmakta olduğu kabul edilmektedir. Gerçekten de bu zamandan sonra söz konusu değişim ve dönüşümlere eşlik eder biçimde birtakım yeni hareketler oluşmaya başlamış, eski hareketlerde alışı olunmayan yeni grupların yeni taleplerle bu hareketler içinde yer almaya başladığı görülmüştür. Bu hareketler çoğunlukla ulus-ötesi bir alana yayılmış ya da böyle bağlantıları olan, dolayısıyla ulusal değil küresel ölçekte var olan hareketlerin birer parçası konumunu almışlardır. Bu yıllara dayandırılan küreselleşme olgusu aynı zamanda post-endüstriyel toplum yaklaşımını da beraberinde getirmiş; eskisinden kopmuş bir yeni toplumsal yapı söylemi toplumsal hareketlerin de eskisinden ayrık olduğu düşüncesinin gelişimini sağlamıştır.

Yeni toplumsal hareketler kuramı, Kuzey Avrupa ve Batı Avrupảnın post-endüstriyel toplumlarında son toplumsal hareketlerin yeni bir odağı olduğunu önermektedir (Mcdam, McCarthy ve Zald, 1988; Pakulski, 1993; Jenkins ve Wallace, 1996'dan aktaran Macionis, 2012: 616). Post-endüstriyel toplum işçi sınıfının zayıflaması/yok olması ve yerini geniş bir hizmetler sınıfına bırakması ile özdeşleştirildiğinden, bu dönemdeki hareketler de ağırlıkla işçi sınıfı mücadelesinden, dolayısı ile eski tip toplumsal hareketlerden bağımsız görülmektedir. $\mathrm{Bu}$ bağlamda yeni toplumsal hareketlerin konuları itibariyle ekonomik değil sosyal olanı ele aldığı, sınıfı değil kimliği öne çıkardığı iddia edilmektedir. Doğrudan ekonomik talepler ve hak arayışlarının dışında ya da ötesinde yaşam tarzı ve kimliklerle ilgili birtakım sosyal ve fiziksel konuların yeni toplumsal hareketlere zemin oluşturmakta olduğu doğrudur; ancak ne bu konular ilk bakışta görüldüğü gibi tümüyle yenidir ne de ekonomik olan ya da sınıf varlığını tümden yitirmiştir.

Yeni toplumsal hareketler, küresel ekolojiye, çevre sorunlarına, kadınların ve LGBT bireylerin sosyal duruşlarına ve hayvan haklarına odaklı, savaşa karşı uluslararası hareketler olarak tanımlanmaktadır. Ancak yeni toplumsal hareketlerin odaklandığı konuları eski hareketlerde hiç konu edilmemiş ve ilk defa tartışılır ya da uğruna mücadele edilir hale gelmiş konularmış gibi ele almak oldukça abartılı bir yaklaşımdır. "Örneğin kadın hakları hareketi, onlarca yıldır işçi örgütlerinin odaklandığı sorunların aynılarına (iş yeri koşulları ve ücretler) odaklanmaktadır. Benzer şekilde ABD’nin askeri gücünü protesto eden pek çok insan, öncelikli amaçlarını tüm dünyada ekonomik eşitlik olarak kabul etmektedir” (Macionis, 2012: 616). Yeni toplumsal hareketlerin konu edindiği "bireysel özgürlük, eşitlik, katılım, barış ve dayanışmacı toplumsal örgütlenme gibi değerler hiç de "yeni" değildir. Bu değerler ve ahlaki normlar, burjuvazi ve iş̧̧i sınıfının ilerlemeci hareketlerinden miras alınmıştır" (Coşkun, 2006: 74). Öyle görünüyor ki bugün yeni gibi görünen bazı konular geçmişte de toplumsal hareketlerin önemli alanlarını oluşturmuştur ve geçmişe ait gibi görülen ekonomik konular da bugünün toplumsal hareketlerinde kendine yer bulmaktadır.

Oysa çoğunlukla yeni toplumsal hareketlerin geçmişte işçi örgütlerinin öncülük ettiği eski tip sosyal hareketlerden belirgin biçimde ayrıldıkları kabul edilmektedir. Kimi yazarlar (Jenkins ve Wallace, 1996; F. Rose, 1997), yeni toplumsal hareketlerin geçmişteki toplumsal hareketler gibi işçi sınıfının güçlü desteğini almak yerine genellikle orta ve üst-orta sınıf tarafından desteklenmekte olduğunu iddia etmekte ve bunu bu sınıfların işçi sınıfına göre daha varlıklı ve ekonomik konularda 
muhafazakar olmaları ile açıklamaktadırlar. Onlara göre "ABD’de ve diğer zengin ülkelerde, yüksek eğitimli profesyonellerin -yeni sosyal hareketleri desteklemesi muhtemel insanların- sayısı artmaktadır; bu, hareketlerin büyüyeceğine işaret eden bir gerçektir” (Macionis, 2012: 616).

Ancak, her ne kadar yeni toplumsal hareketler odaklandıkları konular ve katılımcılarının sinıfsal yapılarıla eski hareketlerden ayriliyor olsalar da, bu durum ekonomik kaygı ve çatı̧̧maların artık belirleyici olmadığı, sınıfın önemini yitirdiği ya da orta ve üst-orta sınıfın sırf ekonomik olandan uzak olduğu için bu eylemlere katıldığı/bunları desteklediği anlamına gelmez. Sınıf vardır ve hala belirleyicidir. Yeni toplumsal hareketlerin tabanının ağırlıkla geçmişin işçi sınıfı tarafından değil bugünün orta sınıfı tarafından oluşturulduğu doğrudur; ancak dönüşüme uğrayan tam da bu orta sınıftır. Post-endüstriyelleşme büyük hizmet çalışanları kitleleri yaratırken, onları proleterleştirmiştir de; böylece yeni hareketlerin tabanını da bu yeni proleterleşmiş orta sinıf oluşturmaya başlamıştır.

Hardt ve Negri (2004: 86), siyasal aktivizmin, sınıf mücadelesinin ve devrimci örgütlenmenin kimi biçimlerinin zamanının artık geçtiğini ve bunların ölümünün en önemli nedenlerinden birinin bizzat çokluğun geçirdiği dönüşüm olduğunu belirtmektedirler. Onlara göre günümüzde toplumsal sınıfların küresel bileşiminin dönüşümü, maddi olmayan emeğin hegemonyası ve ağ yapılarından kaynaklanan yeni karar alma biçimleri, bütün devrimci süreçlerin koşullarını köklü bir biçimde değiştirmektedir ve bu nedenle bugünkü ayaklanma deneyiminin de tekrar keşfedilmesi söz konusudur.

Gouldner (1978a ve 1978b), Giddens (1999), Lash ve Urry (1987) gibi yazarlar, işçi sınıfının yenilgisini, kapitalist sistemin içinde yeni ücretlilik sistemlerinin gelişmesi ve teknolojik gelişmelere paralel olarak işçi sınıfının dışında farklı ücretli çalışan kategorilerinin ortaya çıkması ile açılamaktadırlar. Gouldner (1978a ve 1978b), Inglehart ve Flanagan (1987), Rohrschneider (1990) ve Pakulski (1993) gibi yazarlar, ortaya çıkan bu yeni orta sınıfın işçi sınıfından yalnızca aldığı ücret ve yaptığı işle ayrılmadığını; yeni orta sınıfın aynı zamanda materyalist değerlerden post-materyalist amaç ve değerlere ve sınıf temelli siyasal kutuplaşmadan değer temelli siyasal kutuplaşmaya geçişin simgesi sayıldıklarını ileri sürmüştür. Buechler (1995), Inglehart (1990), Parkin (1968) gibi teorisyenlere göre de, artık endüstriyel toplumun araçsal sorunlarından uzaklaşılmıştır ve post-endüstriyel dönemin yaşam sorunlarına geçilmiştir. Bu nedenle yeni orta sınıfın benimsediği değerler en iyi ifadesini işçi hareketlerinde ya da herhangi bir sınıf hareketinde değil, "Yeni Toplumsal Hareketler"de bulmaktadır (Coşkun, 2006: 68).

Offe $(1985,1987)$, Wallerstein ve Balibar (1993) ve Williams (1989) gibi yazarlar ise, eski ve yeni toplumsal hareketlerde sınıfsal anlamda bir kopuş olmadığını ve yeni hareketlerin ileri kapitalizm ile güçlü bağları olduğunu savunmaktadırlar. Savranın (1992: 9) süreklilik teorileri olarak adlandırdığı bu yaklaşımlara göre ortaya çıkan yeni çelişki ve antagonizmalar, emek sermaye çelişkisinin karmaşıklaşmış dolayımlarıdır (Coşkun, 2006: 74). Offe’ye göre (1985: 831-832) yeni hareketlerin aktörleri, kendilerini yerleşik siyasal ve ekonomik kodlarla tanımlayamamakla birlikte, bu hareketlerin tabanı bütünüyle belirsiz de değildir; yeni orta sınıf, eski orta sınıfın unsurlarından (çiftçiler, esnaf ve zanaatkarlar) ve doğrudan emek piyasasında bulunmayanlardan, yani öğrencilerden, işsizlerden ve ev kadınlarından oluşmaktadır (Coşkun, 2006: 74). 
Benzer biçimde Wallerstein ve Balibara (1993: 47-49) göre de yeni hareketler kapitalizm ile bağlantılıdır; kapitalizmin temel özelliklerinden biri, artı değeri arttırmak için ücretli emekle çalışanların çoğalması; diğeri ise emek gücünün değerini azaltmak amacıyla ücretli emek içinde yapısal birtakım tabakalaşmalar yaratılmasıdır. "Bu anlamda cinsiyetçilik, ırk ayrımcıllğ̆ türünden ayrımlar kapitalizmin lehine olarak tabakalaşmış ve farklılaşmış bir ücretli emek yaratır. Dolayısıyla kapitalizm, bir taraftan bütün insanların ücretli emeğe katılımını sağlarken diğer taraftan emek gücü arasında ırkçı, cinsiyetçi vb. ayrımlar üretir” (Coşkun, 2006: 74). Williams da (1989: 167), barış hareketi, ekoloji hareketi, kadın hareketleri, insan hakları savunucuları, üçüncü dünya ile dayanışma, kültürel yoksulluk ve bozulmaya karşı kampanyalar gibi hareketlerin hepsinin yanlış bir biçimde "sınıf politikasının ötesine geçmek" biçiminde yorumlandığını, oysa bu sorunların hepsinin bizi tekrar sınıflar sistemine götürdüğünü savunmaktadır (aktaran Coşkun, 2006: 75).

Yeni toplumsal hareketlerin ortaya çıkmaya başladığ $1960^{\prime} l 1$ yılların sonunda, Avrupa ve ABD’nin toplumsal yapısındaki değişmeler hareketlerin başlıca aktörleri olan yeni grupların görünür olmasını sağlamıştır. Eski örgüt yapıları içinde görünmez olan ve dar bir işçi sınıfı tanımı içine hapsedilen toplumsal muhalefet, dönüşen üretim ilişkilerine bağlı olarak ortaya çıkan yeni sınıfsal yapıyla biçimlenmeye başlamıştır. Bu kapsamda hem gelişen hizmetler sektörünün proleterleşen beyaz yakalı ücretli emekçileri hem de eski toplumsal hareketler içinde yeterince sesini duyuramayan kadınlar, gençler, etnik azınlıklar ve LGBT bireyler, yeni toplumsal muhalefetin başlıca temsilcileri haline gelmişlerdir.

Arrighi, Hopkins ve Wallerstein’a göre (2004: 42), sistem karşıtı hareketlerin daha önceki modellerinden kopuşunu ve karşı konumlanışını en açık biçimde gösteren şey, bu yeni hareketlerin bürokratik yapıların sınırlarını ve tehlikelerini, kendi temalarından biri olarak ele almalarıdır. Bu hareketler yalnızca onları dizginlemeye ve ezmeye çalışan devletler, üniversiteler ve partiler gibi çeşitli bürokratik güçlere değil, aynı zamanda onları yeni bürokratik örgütlerin oluşumuna ve eskilerinin güçlendirilmesine yöneltmeye çalışan çabalara da karşıdır.

"Yeni toplumsal hareketlerin anti-bürokratik ivmesi başlıca üç eğilime bağlanabilir: Önceki sistem karşıtı hareketler dalgasının bir sonucu olarak, bürokratik örgütlerin gücünün muazzam ölçüde genişlemesi ve derinleşmesi; bu örgütlerin ortaya çıkıp genişlemelerini sağlayan beklentileri yerine getirme yeteneklerinin azalması; ve bürokratik örgütlerin dolayımına girmeyen doğrudan eylem biçimlerinin etkisinin artması" (Arrighi, Hopkins ve Wallerstein, 2004: 42-43).

1960’lı ve 1970’li yıllarda, Birleşik Amerika’da öğrenci ve Siyah hareketleri ve savaş karşıtı hareketler; Japonya ve Meksika’da öğrenci hareketleri; Avrupa’da işçi ve öğrenci hareketleri; Çin'de Kültür Devrimi ve 1970'li yılların kadın hareketleri, dünya-tarihsel standartlar açısından, aynı dönemde ortaya çıkmışlar ve bürokratik örgütlerin dışında ve hatta onlara karşı bir duruş geliştirmeleriyle de 'yeni' hale gelmişlerdir (Arrighi, Hopkins ve Wallerstein, 2004: 40). Batı Avrupa'da yeni toplumsal hareketlerin ortaya çıkışını eski bürokratik örgütlerin yeni toplumsal grupların taleplerini karşılayamamalarına bağlayan Arrighi, Hopkins ve Wallerstein (2004: 86- 
87), sosyal demokrat partilerin ücretli emek gücünün büyüyen üç kesime politik bakımdan seslenmekte yetersiz kaldıklarını ve bu grupların yeni toplumsal hareketlerin başlıca aktörleri olmalarının tesadüf olmadığını vurgulamaktadırlar. Böylece maaşlı meslek sahipleri, barış/ ekoloji/alternatif yaşam tarzı hareketlerinin; "kadınlaşmış" hizmet sektörü, kadın hareketlerinin; "etnikleştirilmiş" vasıfsız ya da yarı-vasıflı işgücü ise "azınlık" hakları/“içteki Üçüncü Dünya” hareketlerinin toplumsal temelini oluşturmuştur.

\begin{abstract}
"İşçilerin hakları sonuçta tüm diğerlerini ayakta tutan temeldir. İşçilerin hakları olmaksızın ötekilerin sahip olabileceği türden "haklar”, yayınlanmış kararnameler olmaktan öteye gitmez; "devlet olma halinin” cepheleşme ilişkisini biçimlendiren özgül aygıtı tarafından kolayca feshedilebilir. Bizim bugünkü varoluş koşullarımız içinde başka her konuda olduğu gibi burada da cepheleşme ve söylem alanını sermayeemek ilişkisi düzenlemektedir” (Arrighi, Hopkins ve Wallerstein, 2004: 91-92).
\end{abstract}

Arrighi, Hopkins ve Wallerstein (2004: 110), gelecekte toplumsal cinsiyet, kuşak, etnik kimlik, ırk, fiziksel özür ve cinsellik temelinde dezavantajl konumdaki statü gruplarının taleplerinin daha da güçleneceğini belirtmektedirler. İlişkileri ve dünya toplumsal yapıları içindeki özgüllükleri bakımından hepsi birbirlerinden derin bir şekilde farklı olan bu altı statü grubu, şu üç özelliği paylaşmaktadır: Tümü yeni solun eski solu eleştirisinin zemini olmakta; tümü emek-sermaye ya da devlet-sivil toplum kadar güçlü çelişkiler hâlini almakta; ve tümünün ezilenleri yalnızca yapısal değil ideolojik olarak da toplumsal cinsiyet, kuşak, etnik kimlik, ırk, sağlıklılık ve cinsellik ilişkileri bakımından üstünlük/zayıflık varsayımlarının toplumsal bilinçten silinmesi anlamında açık bir biçimde toplumsal eşitliği gözetmektedir.

Yeni toplumsal hareketlerin eski solu eleştirmesi ve bu anlamda yeni solun taşıyıcısı olması vurgusuna başka yazarlarda da rastlanmaktadır. Clark ve Lipset’e (2010) göre geleneksel sol, mavi yaka temelli olup sinıfsal konular üzerinde durmaktadır. 'Yeni siyaset', 'yeni sol,' 'post-burjuvazi' ya da 'post-materyalizm' gibi isimler alabilen ikinci sol ise, geleneksel siyasal konulardan çok toplumsal konulara ağırlık vermektedir ve buna bağlı olarak da mülkiyet sahipliği ve üretim araçlarının denetimi artık en ateşli tartışma konuları olmaktan çıkmaktadır. Ancak yazarlar yaşanan değişimin çok da abartılmaması gerektiğinin altını çizmektedirler. Örneğin, Marsh (1975: 28) Britanya verilerinden yola çıkarak, post-materyalistlerin görece genç, zengin, eğitimli ve ideolojiye ilgili olduklarını; ancak yeterli paraya sahip olma konusunda materyalistlerden farklı düşünmediklerini ortaya koymuştur (aktaran Clark ve Lipset, 2010: 291). Sözü edilen Britanya toplumunda, 1931'den 1961'e kadar geçen sürede orta düzey kadrolar ve nitelikli işçi/ çalışan oranlarındaki artışa ek olarak serbest meslek sahibi ve üst düzey kadroların oranının iki katına çıktığı (\%2'en \% 4'e), yarı nitelikli çalışanlar azalırken niteliksiz işçilerin oranının da yarı yarıya düşmüş olduğu (\%18’den \%9'a) görülmektedir (L’Encyclopédie du XXe Siècle, 1993: 102).

1960’lı yılların sonlarından itibaren Avrupa ve Amerika’nın eski endüstrileri küçülmeye başlamış, işsizlik artmış, yarı-zamanl, geçici ve güvencesiz yeni çalışma biçimleri ortaya çıkmış, sendikalar artan devlet düzenlemelerine maruz kalmış ve emek hareketi zayıflamaya başlamıştır (Fulcher ve Scott, 2011:669). 1970'li yıllardan itibaren endüstrinin payı azalmaya, hizmetlerin pay1 
ise artmaya devam etmiştir. 1980'li yıllarda İngiltere'de Thatcher'ın, ABD'de Reagan’ın, Türkiye'de ise Turgut Özal'ın neoliberal politikaları, refah devletinin sona erişini ve muhafazakarlığın yükselişini beraberinde getirmiştir. 1970-1990 döneminde imalat sektöründeki istihdamdaki gerilemeye dikkat çeken Castells, 1990'larda bütün G-7 ülkelerinde nüfusun büyük kısmının hizmet işlerinde istihdam edildiğini ifade etmektedir (Castells, 2005: 285-286). 1991'de ABD'deki işgücünün yüzde 57,3'ünü oluşturan beyaz yakalı işgücü oranının, yüzde 50'nin altında kaldığı Almanya ve Japonyàda bile hızla yükseldiği görülmektedir (Castells, 2005: 296-298). Kapitalizmin bu yeni biçiminde, yükselen kentleşme, küreselleşme ve teknolojik gelişmelerle birlikte imalat sektörü zayıflarken, hizmetler gelişmekte; dolayısıyla mavi yakalılar azalırken, beyaz yakalıların oransal ağırlığı artmaktadır. Ancak hizmet çalışanlarının istihdamdaki oranındaki artış gözle görülür olsa da, yeni uygulamalar hizmet çalışanlarını daha ayrıcalıklı hale getirmemekte, aksine diğer işçi gruplarına yaklaştırarak işçileşmelerine neden olmaktadır. Yeni toplumsal hareketlerse tam da bu yeni proleterleşen orta sınıfın ortaya çıkışına paralel olarak yaygınlık kazanmaktadır.

Toffler (1981), Üçüncü Dalga adını verdiği post-endüstriyel toplumdaki yeni bireysel "kafa emekçileri”"nin sendikalardan daha kurumsal, homojenlikten daha uzak olan kendi örgütlenme biçimlerini bulacaklarını, sendikalara katılırlarsa da, sendika yapısı, pratiği ve ideolojisinde önemli değişiklikleri zorlayacaklarını savunmaktadır. Böylece fabrika sisteminin sonu ve kitlesel olmayan üretim ve bölüşüme kayışın yarattığı karşı-koşulların etkisiyle, kitlesel olmayan siyasal hareketler için bir zemin oluşacak, ancak kafa-emekçileri birlik içinde bir çoğunluk oluşturmada diğer herhangi bir gruba göre daha çok zorlanacaktır (Frankel, 1991: 242-243).

Türkiye'de de son yllarda dünyada olduğu gibi hizmetler sektöründe genel olarak oransal bir büyüme olduğu görülmektedir. 2012 verilerine göre Türkiye genelinde endüstrinin istihdam içindeki payı azalırken, hizmetler sektörü 713 bin kişilik istihdam artışı ile toplam istihdam artışının neredeyse tamamını yaratmıştır (TISK, 2012). Beyaz yakalı çalışanların artışına, çalışma koşullarındaki esneklik, belirsizlik ve güvencesizlik eşlik etmekte; artan işsizliğin ve toplu işten çıkarmaların, beyaz yakalılar için bir sonucu da örgütlenme yönünde bir hareketliliğin ortaya çıkması olmaktadır. Bu dağınık örgütlenme deneyimlerine Plaza Eylem Platformu (PEP), Çağrı Merkezi Çalışanları Derneği (ÇMÇDER) ve Bilişim ve İletişim Çalışanları Dayanışma Ağı (BIÇ̧DA) gibi beyaz yakalı oluşumlarını örnek göstermek mümkündür. Bununla beraber toplumsal muhalefetin yeni aktörleri olarak bu yeni proleterleşen orta sınıfın Türkiyéde yeni toplumsal hareketler kapsamında gerçekleşen Haziran 2013’teki Gezi olaylarında da başrolde olduğu görülmüştür.

Beyaz yakalı işçiler, gençler, öğrenciler, kadınlar, etnik ve dini azınlıklar ve LGBT bireyler gibi yeni toplumun dezavantajlı grupları, üretim ve sınıf ilişkilerinden bağımsız olmamakla birlikte yeni biçimlerde, yeni toplumsal hareketler içinde yerlerini almaktadırlar. LGBT bireylerin yeni toplumsal hareketler içinde öne çıan gruplardan birini oluşturması, kendilerine yönelik toplumsal önyargı ve ayrımcllıklarla baş etme stratejileri geliştirmelerini gerekli kılmıştır. $\mathrm{Bu}$ nedenle bir toplumsal hareket olarak LGBT hareketinin gelişim seyrini ve sınıfsal karakterini analiz etmeden önce eşcinsel kimliğin toplum ve iktidar tarafından nasıl algılandığı üzerinde durmakta fayda vardır. 


\section{Dünyada ve Türkiye'de LGBT Gerçekliği}

Hetero-ataerkil iktidarın, düzenin korunması için farklı cinsel yönelimlerle mücadelesi, İkinci Dünya Savaşı sonrası dönemde belirginlik kazanmıştır. Savaş sonrası Batı dünyasında kurgulanan yeni ekonomik-politik düzen kendisine karşı tehdit oluşturabilecek mavi yakalı iş̧i hareketini sosyal refah politikalarıyla göreceli olarak pasifize etmiştir; ancak ulus-devletlerce taviz verilemeyecek bir konu hetero-ataerkil siyaset olmuştur. Zira "ulus-devletlerin bekalarını sürdürme çabaları, heteroseksüellik dışındaki cinsellik biçimlerine açıkça karşıdırlar, çünkü homoerotizm (erkek) vatandaşları birbirlerine ve vatana bağlayan cinsellikten uzak, masumane kardeşliği (homososyallik) istikrarsızlaştırır” (Özbay, 2011: 195). Bu nedenle ulus-devletlerce yeniden kurgulanan çekirdek aile hayatı ve "normal" hetero cinsellik (Baba, 2011) bir yandan toplumsal düzenin sağlanması ve korunması için diğer yandan da ulus-devletin savaşta ve barışta ihtiyaç duyduğu asker/işçi nüfusunun garanti altına alınması ve pazarın arzına yanıt verecek bir nüfusun idame edilmesi için gerekli görülmüştür. Altman (1972) ve Mieli (1980) gibi kuramclar da bu nedenle aileyi sermayenin emek kaynağı ihtiyacını ve devletin tabi kılma ihtiyacını karşılayan bir heteroseksüellik fabrikası olarak değerlendirmişlerdir. Dolayısıyla eşcinsel arzunun bastırılması, genel bir otoriterciliğin parçası olmakla birlikte çok özel nedenler de içermektedir (Connell, 1998: 64). Bu hetoroseksüellik fabrikasının işlemesi için ise cinselliğin kontrol altına alınması gerekmektedir:

"Çiftlerin, ana babaların ve çocukların, tehlikeli ve tehlikeye maruz gençlerin
cinsel etkinliklerinin içine sızan, onları korumaya, ayırmaya, önlemeye çabalayan,
her yerde tehlike olduğunu belirten, uyarılarda bulunan, saptamalara başvuran,
raporlar toplayan, tedaviler düzenleyen tüm toplumsal denetimler; işte tüm bu
odaklar, cinsellik çevresinde, hiç bitmeyen ve cinsellikten söz etmeye kışkırtan bir
tehlikenin bilincini artırma yoluyla söylemler oluşturur ve yayarlar" (Foucault,
2003: 30-31).

ABD'de savaş dönemi ve sonrası dönem, LGBT bireyler için çeşitli avantajlar yaratmıştır. Bunların bazılarını lezbiyenler de dâhil olmak üzere kadınların erkeklerin bıraktığı alanlarda çalışmak için sanayi sektöründe yer alması, kırsaldan gelen eşcinsellerin ordu bünyesinde farklı yörelerden gelen diğer eşcinsellerle tanışması, savaş sonrası taşralı birçok eşcinselin büyük kentlerde kalması olarak sıralamak mümkündür. Böylece LGBT bireylerin kamusal alanda görünürlüklerinin artmaya başlaması, iktidarı zaman kaybetmeden harekete geçmeye yöneltmiştir. Cadı avına çıkan Cumhuriyetçi Senatör Joseph McCarthy tarafından "komünist sempatizanı" olduğu iddia edilenlerin yanı sıra eşcinsellere karşı da bir plan yürürlüğe konulmuştur (Johnson, 2004). McCarthy ile ilişkili House Un-American Activities Committee gey ve lezbiyenlerin ülkenin istikrarı için bir tehdit oldukları yönünde bir kampanya yürütmüş ve eşcinseller hakkında dezenformasyon üretip, çeşitli söylentiler yaymıştır (Kaiser,1998: 72). Bu kampanya meyvelerini vermiştir; siyasal iktidar, tıbbi otorite, resmi söylem ve medya eşcinselliğe karşı harekete geçmiştir. Bunlar aynı cinslerin cinsel ve duygusal ilişkisinin sapkınlık ve topluma tehdit oluşturan bir psikiyatrik hastalık olduğu algısını topluma yaymışlardır. Böylece egemen gruplar, fiziksel 
şiddete başvurmaksızın yanlış bilgilendirme, taraflı haber yapma, zehirleme, şantaj ve söylentiler vasıtasıyla kendi isteklerini sivil topluma ve devlet aygıtına dayatmışlardır. Simgesel şiddet fiziksel şiddeti de meşrulaştırmıştır. Bu kampanyaya müteakiben, gey ve lezbiyen bireyler saldırılara uğramışlardır. Başta orduda (D’Emilio ve Berube, 1984), diğer hükümet organlarında ve kamu kurumlarında çalışanlar olmak üzere çok sayıda gey ve lezbiyen birey işlerinden olmuştur (Adam, 1987: 58-59). Bunlardan bazıları yasaları ihlal ettikleri gerekçesiyle hapsedilirken, diğerleri elektroşok, iğdiş, kusturma, hipnotizma, lobotomi gibi yöntemlerle akıl hastanelerinde tedavi altına alınmıştır (Carter, 2004: 14-15; Katz, 1976: 181-197; Adam, 1987: 60). Gey ve lezbiyenlerin uğrak yeri olan kafeler ve publar resmi otoriteler tarafından kıskaca alınmıştır. Tüm bu baskı ve yıldırma politikaları gey ve lezbiyen bireyleri toplumdan dışlanmaya, gettolaşmaya ve kendi alt kültürlerini oluşturmaya itmiştir (Carter, 2004: 14-15). Bu gettolaşma eşcinsellerin kentlerin yoksul semtlerinde Afro-Amerikalılar, yalnız yaşayan feminist kadınlar, bohemler gibi toplumun diğer "marjinal" gruplarıyla zaman içinde etkileşim ve dayanışma ağları kurmalarını sağlamışıtır. Zaman içinde ABD'de LGBT bireyler çeşitli hakları için verdikleri mücadelede önemli kazanımlar elde etmiş, hatta çok sayıda eyalette eşcinsel evlilikler dahi yasal hale gelmiştir.

Türkiye, geleneksel olarak ABD'den çok Akdeniz, Orta Doğu ve Latin Amerika bölgeleriyle ortak bir cinsiyet/toplumsal cinsiyet düzenini paylaşmaktadır (Murray, 2000'den aktaran Bereket ve Adam, 2006: 131). Bu bölgelerde erkek erkeğe cinsel ilişkilerin, erkeksi kabul edilen bir "aktif” erkek ile davranışları, sesi ya da kıyafetleri itibariyle kadınsı özellikler göstermesi beklenen bir "pasif" erkek arasındaki toplumsal cinsiyet ayrımını içermesi beklenmektedir (Tapınç, 1992: 46'dan aktaran Bereket ve Adam, 2006: 131-132). Osmanlı döneminde, tıpkı Roma İmparatorluğu geleneğinde olduğu gibi (Bourdieu, 1998), "kulamparacllı", "oğlancillk" şeklinde ifade edilen, bir erkeğin (genellikle kendinden daha genç ya da daha düşük sosyal statüye sahip bir) hemcinsiyle cinsel ilişkide "aktif" olması eşcinsellik olarak algılanmamıştır. Zira cinsel ilişkide aktiflik/baskınlık erkeğe özgü bir özellik olarak görülmüştür. Kimi eşcinsel çiftler dahi bu sosyal hiyerarşiyi kendi ilişkileri içinde aktif/pasif, erkeksi/kadınsı olarak yeniden üretmektedirler (Bourdieu, 1998). Bugün de Türkiye toplumunda benzer bir algılayış geçerlidir. Eşcinselliğin ayıp sayılması, Batı tipi reformlara hız verilen, dolayısıyla kadın-erkek ilişkilerinin normalleşmeye başladığı Tanzimat Dönemi’ne dayanmaktadır (Hür, 2013). Bununla beraber Türkiyede eşcinselliğin ayıp sayılmasının yalnızca pasif ya da kadınsı olan erkek eşcinseller için geçerli olduğu ve bu algının varlığını koruduğu görülmektedir. Örneğin genellikle gey ya da travestilerle cinsel ilişkiye giren "erkek" kendini eşcinsel olarak kimliklendirmez, toplumsal olarak da ona böyle bakılmaz (Hocaoğlu, 2002). Ancak son yıllarda aktif/pasif ayrımının yerini giderek bu ayrımların önemini göreceli olarak yitirdiği gey kimlikleri almaya başlamaktadır (Tapınç, 1992: 46'dan aktaran Bereket ve Adam, 2006: 131-132).

Türkiye'de eşcinselliğe yönelik toplumsal algının, tarihsel süreç içerisinde birtakım değişikliklere uğramakla birlikte, uzun zaman büyük gelişim göstermediği görülmektedir. Türkiye'de eşcinselliği yasaklayan yasalar yoktur; buna karşıllk medeni kanunda "cinsel yönelim" gibi bir ifade de yer almamaktadır. Her ne kadar eşcinsellik yasal olarak bir suç olmasa da, siyasal iktidarlar eşcinselliği kamusal alanda ya yok saymışlar ya da eşcinsellere karşı düşmanca tavırlar sergilemişlerdir. 
LGBT bireylere yönelik ayrımcllğın önemli dönemeçlerinden birini 12 Eylül 1980 askeri darbesi oluşturmaktadır. Askeri yönetim kendine sadece ülkede artan şiddet olaylarına (silahlı sağ-sol çatışması) son verme değil, ayrıca kamu ahlakını da yeniden tasarlama görevini biçmiştir. 1960'larda ABD’nin birçok eyaletinde öteki cinsin kuyafetinin giyilmesinin yasak edilmesi gibi (Adams, 1987: 59), 1980 askeri cunta yönetimi de, sahnede kadın kıyafeti giyen erkeklere yasak getirmiş; bu yasak, İçişleri Bakanlı̆̆ı’nın 19 Mart 1981 tarihli "Bar, pavyon gibi içkili yerlerde, kadın kıyafetiyle erkeklerin çalıştırılmasının engellenmesini içeren” genelgesiyle uygulanmıştır (Öz, 2009). Bu genelge Avrupa Birliği uyum yasaları paketiyle 2002 yllında yürürlükten kaldırılmıştır (Engindeniz Şahan, 2012: 140).

LGBT bireyler, 12 Eylül mağduriyetleri üzerine yapılan çalışmalarda isimleri pek az geçen bir gruptur. Oysa ABD’de yerel hükümetlerin 1950-1960'larda geyleri kentlerden temizleme/süpürme (sweeps) uygulamasının daha ağırını askeri yönetim transgender bireylere karşı yapmıştır:

"1980 askeri darbesi ile yapılan "temizlik”te de travesti, transeksüel ve eşcinseller
saçları kazınarak, İstanbul'dan başka şehirlere sürgüne gönderilmişlerdi. (...) 1980
darbesinden sonra pek çok LGBT bireyin saçlarının kazınarak İstanbul dışına
sürgüne gönderilmesi, pek az kişi tarafından bilinen ve dillendirilen bir gerçek.
Zira etiketleme, mağduriyetler hiyerarşisinde dahi LGBT bireyleri en sona atıyor"
(Öz, 2009).

Toplumsal hayattan dışlanan eşcinsel, özellikle transgender bireyler, birçok göçmen, bekar işçi, öğrenci gibi, 1970’li ylllardan itibaren bir kentsel çöküntü bölgesi haline gelen Taksim ve çevresine yerleşmişlerdir. Özellikle çalışma yaşamından dışlandıkları için fuhuş sektöründe çalışmaya itilen transgender bireyler bazı sokaklarda (Pürtelaş Sokak olarak bilinen Ülker Sokak, şimdiki adı Halas Sokak olan Abanoz Sokak, daha sonra adı Başkurt Sokak olarak değiştirilen Sormagir Sokak) getto hayatı yaşamak durumunda kalmışlardır (Gürsu ve Elitemiz, 2012). Bu gettolaşma aralarında dayanışma ağları kurmalarına izin verirken, yaşam alanlarının sınırlarını da belirlemiştir (Selek, 2001). 1990'ların başında transgender bireyler bu sokaklardan kolluk kuvvetleri ve mafyatik oluşumların marifetiyle uzaklaştırılmışlardır. Bu dönemde, sınıfsal kökenleri aynı olsa da klasik burjuvaziden birçok bakımdan farklılık gösteren, yeni kapitalist üretim ilişkilerinin yarattığı, farklı tüketim alışkanlıklarına sahip yeni bir sosyal sınıf doğmuştur (Uysal, 2006: 79). Bu sınıfın ihtiyaçları doğrultusunda Taksim ve çevresi soylulaştırılmaya başlanmıştır. Yeni dönemde seks işçilerine bölgede yaşam hakkı tanınmamıştır. Ancak bu sokakları terk etmeye zorlananların yerlerini dolduracak olan yuppi, bobo/bohem, serbest meslek sahibi, varlıklı birçok gey ve lezbiyenin bölgeye yerleşmesinde bir sakınca görülmemiştir.

Kimlik mücadelesi veren Türkiye LGBT hareketinin kamusal alanda varlığını göstermekte zorlanmasının en önemli nedenlerinden biri hetero-ataerkil resmi söylem ve medya dili (hastalık, fuhuş, gayri ahlaki vs.) ile beslenen heteroseksüel toplumun eşcinsellere yönelik nefreti ve dışlayıcı tavrıdır. Bahçeşehir Üniversitesi tarafından 2009'da yapılan "Radikalizm ve Aşırıcılık" adlı araştırmada, 34 ilde 1715 kişiye sorulan "Kiminle komşu olmak istemezsiniz?" sorusuna katılımcıların \%87’si "eşcinsel” kişiler olarak yanıt vermiştir (Esmer, 2009). Aynı soruya aynı 
şekilde verilen yanıt oranı 2011 Türkiye Değerler Araştırması'nda \% 84, 2012 Türkiye Değerler Araştırması'nda ise yine \% 87'dir (Esmer, 2012). Verilen yanıtlarda eşcinselleri, 2011'de AIDS hastaları, nikahsız yaşayanlar ve Tanrı'ya inanmayanlar; 2012'de ise içki içenler ve yine AIDS hastaları takip etmektedir. Sözü edilen üç araştırmanın sonuçlarında da, eşcinsellerin en çok "rahatsızlık duyulan" grup olması dikkat çekicidir.

Avrupa Konseyi üyesi 47 ülkede homofobi, transfobi, cinsel yönelim ve cinsiyet kimliğine dayalı ayrımcılık üzerine yapılan "Avrupa’da Cinsel Yönelim ve Cinsiyet Kimliğine Dayalı Ayrımcllk" (Council of Europe, 2011) araştırması da, Türkiye’nin LGBT bireylere yönelik ayrımcılıkta diğer ülkeler içindeki yerini göstermesi bakımından özellikle anlamlıdır. "Eşcinsel bir insan ülkedeki en yüksek siyasi pozisyona gelmeli mi?” sorusuna, 2008'de İsveç, Danimarka ve Hollanda'da yaşayanlar en olumlu yanıtları verirken, Bulgaristan, Kıbrıs ve Romanya'da en olumsuz yanıtlar verilmiş; 2009'da aynı soruya verilen olumsuz yanıtın en fazla olduğu ilk üç ülke arasına Türkiye de girmiştir (European Commission, 2009: 91).

Avrupada 2005'te yapılan bir başka araştırmada, “Gey erkekler ve lezbiyenler kendi hayatlarını diledikleri gibi yaşamak konusunda özgür olmalıdır” ifadesine katılım İsveç, Hollanda ve Danimarka'da en yüksek düzeylerdeyken (\% 90), bu ifadeye katılmama oranının en yüksek (\% 70) olduğu ülkelerin Ukrayna, Romanya, Rusya ve Türkiye olduğu görülmüştür (European Social Survey, 2005).

Türkiye'de LGBT bireylere yönelik ayrımcı tutum yaşamın birçok alanında karşıllı̆ını bulmaktadır. Örneğin Türk Silahlı Kuvvetleri’nde erkekler için zorunlu olan askerlik hizmetinden sadece engelliler ve eşcinsel olduğunu ispat edenler muaf tutulmaktadır. Ancak eşcinsel olduğunu ispat etmek için bireyi küçük düşürücü belgeler istendiği asker adayları tarafından sıkça dile getirilmektedir (Azizlerli, 2012). Farklı dönemlerde Türkiye’de siyaseti belirleyen figürler tarafından da eşcinselliğin bir hastalık olduğu yönünde açıklamalar yapılmıştır. Örneğin dönemin Kadın ve Aileden Sorumlu Devlet Bakanı Selma Aliye Kavaf'ın, ülkenin en büyük tirajlı gazetelerinden birinin Pazar ekine verdiği röportajda "Ben eşcinselliğin biyolojik bir bozukluk, bir hastalık olduğuna inanıyorum. Tedavi edilmesi gereken bir şey bence» sözleri kamuoyunda yoğun tartışmalara yol açmıştır (Bildirici, 7 Mart 2010). Tüm bunların ötesinde LGBT bireyler aile ve toplumdan gelen fiziki şiddetle karşı karşıya yaşamaktadır. Transgender Europe'un trans cinayetleri raporuna göre 2008-2013 ylları arasında Türkiye’de 34 trans birey öldürülmüsstür (Kaos GL, 18 Kasim 2013).

Bu olumsuzluklara rağmen Türkiyedde sanat, gösteri ve moda dünyasındaki eşcinsel figürlere yönelik tutumun çok daha 1lımlı olduğu dikkat çekmektedir. Örneğin geniş bir hayran kitlesine sahip bir ses sanatçısı olan Zeki Müren’in (1933-1996) eşcinsel ve Bülent Ersoy’un (1952-...) transseksüel olması ayrıca bir tartışma konusu olabilir. Osmanlı toplumunda yüksek sivil memurlarla ve albayların üstündeki askerlere verilen "paşa" unvanıyla anılan Zeki Müren kamusal alanda makyaj yapsa da, kadın kıyafetleri giyse de hiç bir zaman eşcinsel olduğunu açıklamamış, oynadığı filmlerde erkek aşık rolünü üstlenmiş ve mirasını da askerlik hizmeti sırasında hayatını kaybedenlere yardım eden Mehmetçik Vakfı̉na bağı̧lamıştır. Bülent Ersoy ise ameliyatla cinsiyet değiştirmiş, kadın kimliğini her zaman öne çıkarmış ama hiçbir zaman LGBT 
hareketi içinde olmamış, bu bireyleri destekleyici hiç bir eylemde bulunmamıştır (Engindeniz Şahan, 2012: 142). Dolayısıyla medyatik eşcinsel figürlerle halk arasındaki görece olumlu iletişimin gündelik hayattaki ilişkilerde karşılık bulmadığı görülmektedir.

Türkiyede eşcinselliğin sinemadaki yansımalarına bakıldığında da, LGBT bireylere yönelik toplumsal algının ipuçlarını bulmak mümkündür. Eşcinsel temalı ilk sinema yapımının 1962 tarihli "Ver Elini İstanbul" olduğu bilinmektedir. İki kadının ilişkisini içeren bu ilk filmden sonra, özellikle 1974-1979 yılları arasında lezbiyen ilişkiler ticari amaçlarla çekilen seks komedilerinde sömürü aracı haline gelmiştir. Erkek eşcinselliğini ön plana çıkaran filmlerin ilki ise 1980'de çekilen "Beddua"dır. İzleyen yıllarda erkek eşcinselliği temalı filmlerde eşcinsellerin çoğunlukla mutsuz aile mağdurları, tecavüz kurbanları, güldüren, arkadan vuran, dalga geçilecek kişiler olarak sunulduğu görülmüștür (Öztek, 2007).

Sonuç olarak dünyada ve Türkiyedde LGBT bireyler çeşitli biçimlerde ön yargılar ve ayrımcllıklarla karşılaşmış, LGBT kimliğini sahiplenme ve bu kimliği toplumsal alanda açık olarak yaşama, yeni mücadele alanlarını beraberinde getirmiştir. Özellikle kent merkezlerinde kurulan dayanışma ağları LGBT bireylerin bir arada ortak taleplerle hak arayışına girmelerine olanak sağlamıştır. Böylece bir yeni toplumsal hareket olarak LGBT hareketi doğmuştur.

\section{Stonewall'dan Gezi'ye LGBT Hareketinin Seyri}

Sanayi devriminin bir sonucu olarak tarih sahnesine çıkan mavi yakalı iş̧i sınıfı 1960'lara kadar toplumsal hareketlerin başlıca öznelerinden biri olmuştur. Sınıf olgusu merkezinde sendikal örgütler ve dernekler gibi sivil toplum kuruluşları çatısında ekonomik eşitlik maksadıyla yürütülen mücadele tarzı, refah toplumunun geliştiği Batı Avrupa ülkeleri ve ABD'de toplumun farklı katmanlarından gelen, farklılıkları göz ardı edilen/yok sayılan renkli tenlileri, kadınları, toplumun genelinden farklı cinsel yönelimi olanları 1960'lı yıllardan itibaren tatmin etmemeye başlamıştır. Tüm toplumu ekonomik üniteler olarak gören "eski” toplumsal hareketler 1960’lara kadar iktisadi eşitlik ya da refah adı altında toplumsal cinsiyet, ırk ve etnisite gibi diğer sosyal farklılıkların üstünü örterken statükocu, bürokratik, merkeziyetçi erkek egemen dili de yeniden üretmiştir. "Yeni" toplumsal hareketlerin aktörleri, insan ve toplum hayatını tektipleştiren, metalaştıran bu kavrayışa itiraz etmişlerdir (Bertram, 1995).

Yeni toplumsal hareketler içinde anılan LGBT hareketini, cinsel yönelimleri nedeniyle toplumdan dışlanan, bastırılan, marjinalize edilip çoğu zaman yok sayılan bireylerin farklılıklarıyla beraber toplumun eşit bireyleri olarak tanınmaları ve ayrımcılığa uğramamaları için yürüttükleri mücadele olarak tanımlamak mümkündür. İnsanlık tarihi boyunca LGBT bireyler toplumların içinde cinsel kimlikleriyle farklı statülerde var olmuşlardır. Ancak bu bireylerin toplumsal hareketlerin öznesi haline gelmesi, İkinci Dünya Savaşı sonrası tüketim toplumunun zirveye ulaştığı, 1960'larda bütün dünyayı saran özgürlükçü, anti otoriter/cinsiyetçi, barışçı sivil haklar mücadeleleri süreci içinde gerçekleşmiştir. Örneğin Avrupa’da Prag Baharı gibi özgürlükçü dalgalar, Meksika'dan Polonya’ya, Fransa’dan Japonya’ya kadar dünyanın dört bir yanına yayılan öğrenci eylemleri, ABD'deki Vietnam Savaşı karşıtı eylemler ve sivil haklar 
mücadelesi ile Stonewall Ayaklanması içinde yer alan LGBT bireyler, bu mücadeleler içinde hem politikleşmiş hem de toplumda yalnız olmadıklarının farkına varmışlardır.

Bu bağlamda Stonewall Ayaklanması̉nın LGBT hareketi için önemi büyüktür. 1960'ların sonuna gelindiğinde LGBT bireyler, savaş karşıtı liberal gençler, feministler ve AfroAmerikanların başı çektiği sivil haklar aktivistleriyle yakın etkileşim halinde olmuşlardır. Zamanın ruhu olan sosyal eşitlik için kamusal alanda mücadele konusunda LGBT bireyler için dönüm noktası, 28 Haziran 1969 tarihinde ABD’nin New York kentinde farklı alt kültür gruplarının yaşam alanına dönüşen Greenwich Village bölgesinde yer alan ve eşcinsellerin uğrak yeri olan Stonewall Inn isimli bir bara polisin baskın düzenlemesi olmuştur. Baskına karşı LGBT bireyler günlerce mahallede polisle çatı̧̧ıı̧, gösteriler ve direniş eylemleri organize etmişlerdir. Eşcinselliğe ve eşcinsel bireylere karşı baskı uygulayan hetero-ataerkil iktidara bu açık tavır alış ve dayanışma sayesinde LGBT bireyler toplumda yalnız olmadıkları görmüşlerdir. Tarihe Stonewall Ayaklanması olarak geçecek bu ayaklanma diğer eyaletlerde ve tüm dünyada cinsel farklılıkları nedeniyle baskıya uğrayan LGBT bireylere ilham vermiştir.

Türkiye'de de 1990 'lı yılların başından itibaren örgütlü bir toplumsal hareket olma çabası veren, Gezi olayları sırasında görünürlüğü artan ve diğer toplumsal hareketlerin aktörleriyle güçlü etkileşime geçen LGBT hareketinin doğuşu ve gelişimi, Stonewall Ayaklanması'ndan sonra görünürlüğü artan ABD’deki LGBT hareketiyle benzerlikler taşımaktadır.

Türkiye'de toplumsal hareketler büyük ölçüde kırdan kente göç olgusunun hız kazandığ1 1950'li yılların ortalarında başlamışırı. 1960 askeri darbesi sonrası hazırlanan özgürlükçü anayasa, işçi hareketlerinin güçlenmesi ve üniversiteleşmenin yaygınlık kazanması, toplumsal hareketlerin canlanması için verimli bir zemin oluşturmuştur. 12 Eylül 1980 askeri darbesine kadar toplumsal hareketlerin ana ekseni sağ ve sol kutuplaşması ve iş̧̧i sınıfı-öğrenci eylemleri çerçevesinde gelişmiştir. Bu dönem boyunca LGBT bireyler kimliklerini ortaya koyarak kamusal alanda yer alamamışlar ama cinsel kimlik siyasetinden bağımsız bireyler olarak özellikle çeşitli sol örgütlerin üyesi ya da sempatizanı olmuşlardır (Gürsu ve Elitemiz, 2012: 135). 1970’lerin Türk solu eşcinselliğe ve onların kimlik sorunlarına mesafeli yaklaşmış, hatta eşcinselliği, uzlaşmaz sınıfsal çelişkilerin aşırıya varması sonucunda ortaya çıkan, köleci ya da kulluk sisteminin egemen olduğu eski toplumlardan sonra varlı̆̆ını günümüz kapitalist toplumlarında sürdüren bir olgu olarak görmüştür (Perinçek, 2000). Bu mesafeli tutum kimi sol partiler içinde günümüzde hala devam etmektedir (Tar, 2013).

Askeri yönetim 1980 darbesi sonrasında toplumsal muhalefeti susturmuş, geleneksel sağ ve sol siyasal hareketlerin lider kadrolarını bastırma, yıldırma, cezalandırma gibi farklı yöntemlerle politika sahnesinden geçici ya da kalıcı olarak diskalifiye etmiştir. Askeri darbe döneminde yurt dışına kaçan kimi sol aktivistler Avrupa’da savaş karşıtı, çevreci, anarşist, eşcinsel hareket gibi dönemin Türk soluna yabancı birçok yeni akımla tanışmışlardır. Bu akımlar geleneksel sağ-sol siyasetine mesafeli duran, küreselleşen ve neo-liberal ekonomik düzenin etkisi altındaki dünyada, genç kuşaklara cazip gelmiştir. Eski toplumsal hareketlerin ihmal ettiği etnik gruplar, feministler, yeşiller, savaş karşıtları ve eşcinseller bu dönemde örgütlenmeye başlamışlardır. Bu örgütlenme çabalarının en önemlisi, tüm bu "yeni" unsurları tek bir çatı altında toplamayı hedefleyen Radikal 
Demokrat Yeşil Parti girişimi olmuştur. 1986-1987 yıllarında parti için çalışmalar yapılmış, Taksim’de bir lokal dahi kiralanmıştır. Bu girişim başarısızlıkla sonuçlanmış olsa da, Taksim’de kolluk kuvvetlerinin eşcinsellere uyguladığı şiddeti protesto eden 37 travesti 27 Nisan 1987 tarihinde parti lokaline sığınmış ve açlık grevi yapmıştır. Bu olay Türkiye tarihindeki ilk eşcinsel eylemi olmuştur (Güner vd., 2011: 13).

Türkiye LGBT hareketi, yerel ve küresel kapitalist üretim ilişkilerinin ve politikaların sonucu Türkiyede bireyciliğin ön plana çıktı̆̆ı, kentli, tasarruftan çok tüketmeye odaklı, Batı dünyası ile iletişim halinde, eğitimli yeni bir kuşağın yetiştiği 1990'lı yllarda kamusal alana örgütlü olarak çıkabilmiştir. 1993’te Avrupalı eşcinsel örgütlerin de desteğini alarak Türkiye’nin ilk eşcinsel oluşumu Lambdaİstanbul kurulmuştur. Aynı yıl LambdaIstanbul'un Türkiye’de yapmayı planladığı ilk uluslararası Gey-Lezbiyen (Cinsel Özgürlükler) etkinliği valilik tarafından engellenmiştir. ILGA (Uluslararası Gey ve Lezbiyen Dernekleri) üyesi olan oluşum, eşcinsel düşmanı ifadeler içeren bir AIDS broşürünü yayından ve dağıtımdan kaldırtarak LGBT hareketini kamusal alanda bir baskı unsuru haline getirmeyi başarmıştır. 2006 yılında tüzel kişilik kazanan Lambdaİstanbul, uzun yıllar genel ahlaka aykırı bir dernek olduğu gerekçesiyle kamu otoritesince kapatılmak istenmiş, sürdürülen hukuki mücadele sonucu tekrar dernek statüsünü kazanmıştır.

Türkiye'de LGBT hareketinin vücuda gelmesinde önemli yapı taşlarından biri de Kaos GL dergisidir. Dergi 1994'ün Eylül ayında Ankara’da anarşist ideolojiyle bağları olan işçi sınıfı kökenli bir çiftin girişimiyle, bir grup eşcinsel tarafından, maruz bırakıldıkları ayrımcıllğa karşı mücadele etmek amacıyla kurulmuştur. Kurucuları nedeniyle derginin ilk dönem yazılarında anarşist bir ton vardır. Zamanla dergi, kurucularının çizgisinden uzaklaşarak daha liberal bir yayın politikası benimsemiştir (Engindeniz Şahan, 2012: 201). Dergi çevresindeki LGBT bireyler 2005 yılında Türkiye’nin ilk LGBT Derneği Kaos GLyi kurmuşlardır.

Türkiye’nin Avrupa Birliğine üye olabilmek için bir dizi siyasi, hukuki ve ekonomik reformları yürürlüğe koyduğu 2000'li ylllar LGBT hareketinin de kamuoyu önünde görünürlük mücadelesi verdiği döneme denk gelmiştir. Özellikle internet alt yapısının da geliştiği bu dönemde LGBT bireyler arası iletişim ağları daha sıkı örülmüş, bu süreçte LGBT gruplar savaş karşıtı eylemler, 1 Mayıs işçi eylemleri, anti nükleer protestolar gibi başka toplumsal hareketlere destek vermiş, onların eylemlerinde kendi bayraklarını açmışlardır. LGBT hareketinin görünürlük kazanmasındaki en önemli aşama ise, İstanbul'da 2003'ten itibaren düzenlenen Onur Yürüyüşü’ne LGBT bireylerin, toplumun diğer kesimlerinin de desteğini alarak yoğun katılım sağlamış olmalarıdır. Stonewall Ayaklanması’nın yıldönümü niteliğindeki bu yürüyüşe başlangıçta yalnızca otuz kişi katılırken, 2013 yürüyüşünde elli bini aşkın katılımcı yer almıştır.

\section{Türkiye LGBT Hareketinin Sınıfsal Yapısı}

21. yüzyılın karmaşık toplumları için, cinsiyetten bağımsız bir sınıf analizi tasavvur etmek mümkün değildir. Sınıf, cins, cinsiyet, cinsellik, etnik köken, bulunulan yer, beden, din ve inanç sistemleri, anadil, vatandaşlık durumu ve yaş gibi kimlik kategorileri birbirlerine içkindir; içinde bulunulan bağlama ve kamusallı̆ga göre farklı vurgularla hareket etmekle beraber, toplumsal 
dışlanma sistemlerine ve tahakküm matrislerine eklemlenmektedirler (Özbay, 2011: 187). $\mathrm{Bu}$ çerçevede cinsel yönelime bağlı kimlikler ve buna bağlı toplumsal konumlanmayı da sinıf ilişkileri ile bağlantılı olarak ele almak gerekir.

Sosyal sınıf, ideal olarak, gelir, servet, eğitim, aile geçmişi gibi farklı bileşenler ile ölçülür. Barret ve Pollack’ın (2005) ABD'de 18 yaş üstü, 14 yaşından beri aynı cinsle cinsel ilişkiye giren ve kendini eşcinsel ya da biseksüel olarak tanımlayan 2881 erkekle yaptığ 1 araştırmanın sonuçları, böyle bir cinsel yönelime sahip olanların sınıfsal kimliği üzerine bazı önemli ipuçları vermektedir. Gelir, eğitim düzeyi, gey kültür hayatına katılım gibi farklı konularda katılımcılara sorulan soruların sonucunda, gey erkeklerin ağırlıkla orta sınıf ve üstü oldukları ortaya çıkmıştır. İş̧i sınıfına dâhil eşcinsel erkekler, gey kültürü içinde sınıfsal özelliklerinden dolayı daha az görünürlüğe sahiptirler ve daha alt sosyal sınıflara mensup eşcinsellerin kendilerini gey olarak tanımlama oranları çok daha düşüktür.

Türkiyede LGBT hareketi içinde olan bireylerin sosyo ekonomik durumları hakkında elimizde ayrıntılı bir bilgi olmamakla birlikte, sınıf hareketlerinin küresel dünyada benzer dinamiklerden beslendikleri düşünülürse, ABD’de yapılan bu çalışmanın sonuçlarıyla Türkiyedeki durumun benzerlikler göstereceğini savlamak yanlış olmayacaktır.

Türkiye toplumu bugün erkekler arası ilişkinin eskiden beri var olagelen ve değişmekte olan sosyal biçimlerinin heterojen bir birleşimini içermektedir. Öyle ki bazı erkekler sürekli olarak belirli bir davranış biçimi sergilerken, bazıları duruma ya da kişisel tercihine göre birinden diğerine geçiş gösterebilmektedir. Özellikle 1990’ların başlarından itibaren, giderek daha fazla sayıda erkek homoseksüel davranışını kimliğiyle ilişkilendirmeye ve kendini sosyal bir kimlik bağlamında gey olarak tanımlamaya başlamıştır. Her ne kadar geyler erkek erkeğe ilişki kuranlar içinde bir azınlığı oluşturuyor olsalar da sayıları giderek artmaktadır ve Kaos GL gibi örgütler aracılı̆̆ıyla bir cinsel yönelimi savunan aktörler olarak sivil topluma dâhil olmaya başlamışlardır. Homoseksüel nüfusun bu yeni cinsel bilince sahip tabakasına (Tapınç, 1992: 46) daha çok kentli, genç, eğitimli ve orta sınıf homoseksüel erkekler arasında rastlanmaktadır (Bereket ve Adam, 2006: 132).

Değişen sosyo ekonomik yapıyla ve yeni küresel düşüncelerin ve kültürlerin etkisiyle, Türkiye’de yeni toplumsal koşullar ortaya çıkmış; modern gey ve lezbiyen kimlikleri diğer homoseksüel bağlardan farklı özellikler göstermeye başlamıştır: İnsanlar cinsel yönelimleriyle ilgili olarak birbirlerini keşfetmeye ve aile, komşuluk, okul, askerlik, dini mekanlar gibi eskiden beri var olan sosyal ilişki bağlamları dışında yeni büyük ölçekli sosyal ağlar oluşturmaya başlamışlardır. Böylece eşcinsellik, öz-farkındalık ve grup kimliği ile karakterize edilen bir toplumsal biçimlenme halini almaya başlamıştır (Adam, 2001: 170-1'den aktaran Bereket ve Adam, 2006: 136).

LGBT hareketi içinde yer alan eşcinsel bireyleri diğerlerinden ayıran en önemli özellik sınıfsal konumlarıdır. Zira cinsel yönelimin ifade edilebilmesiyle sosyal sınıf arasındaki ilişki farklı ekonomik kaynaklara erişim ve bunun getirdiği özgürlük ortamıyla yakından bağlantılıdır. Sosyo-ekonomik olarak daha avantajlı olan bireyler yeni sosyal ağlar kurarak kimliklerini açık bir 
biçimde yaşayabilmektedirler. Bu noktada yaşanılan mekan, iş ortamı ve kültürel çevreye entegre olabilecek maddi ve sosyal sermayeye sahip olabilmek önemli ölçütlerdir.

Toplum içinde farklı cinsel yönelimlere sahip olan bireyler kimliklerini daha özgürce ifade edebilmek için kentlerde ve kentlerin belirli mahallerinde yaşamak zorundadırlar. Ekonomik kaynaklara sahip olmayı gerektiren, ülke içi kırsal alanlardan kentlere, kentlerden metropollere ve kentlerin çevre bölgelerinden merkezine doğru olan bu tip bir göç, işçi sınıfına mensup LGBT bireyler için daha az mümkündür (Escoffier, 1998'den aktaran Barrett ve Pollack, 2005: 438).

Türkiye’de LGBT kimliği üzerine yapılan çalışmalar son yıllarda artış göstermekte olsa da LGBT bireylerin yaşadıkları mekanlar üzerine fazla çalışma bulunmamaktadır. Ancak Lambdaİstanbul LGBT Dayanışma Derneği’nin "İt iti 1sırmaz!- İstanbulda Yaşayan Trans Kadınların Sorunları" (2008) isimli çalı̧̧masında trans bireylere İstanbul'a göç etme nedenleri sorulduğunda, katılımcıların \%73,2'sinin “özgür ve rahat yaşamak, aile ve çevre baskısından kurtulmak" cevabını verdikleri görülmektedir. ABD toplumunda da durum farklı değildir; her ne kadar ABD'de gey kimliğine yönelik genel bir kabul etme tavrı olsa da bunun yüksek gelirli ve iyi eğitimli bireylerin yaşadığı kentlerde ve banliyölerde çok daha yüksek olduğu görülmektedir (Bowman, 2004'ten aktaran Barrett ve Pollack, 2005: 438). Geleneksel olarak güvenlik sağlayan kapalı gey gettoları giderek önemini kaybederken, kent merkezleri, özellikle milyonları aşan nüfuslarıyla metropol merkezleri, farklı yaşam tarzlarına sahip bireyleri içine rahatlıkla kabul etmekte ve bu nedenle kendilerini gey ve lezbiyen olarak tanımlayanlar yerleşmek için buraları tercih etmektedirler. Karakteristik olarak bu muhitlerde konut, yiyecek, eğlence gibi geçim giderleri daha yüksektir; bu da coğrafi yerleşime bağlı bir sınıf eğilimi doğurmaktadır. Bu yaşam giderlerini karşılayabilecek gücü olanlar bu semtlere taşınmakta, bu muhitlerde yalnız ya da cinsel/duygusal partnerleriyle beraber cinsel kimliklerini daha rahat yaşayabilmektedirler (Barrett ve Pollack, 2005: 438).

İş yeri ve çevresi de cinsel yönelimin ifadesi ve yaşanması açısından önemli bir etkendir. Daha az eğitimli insanların çalıştığı ve daha az gelirin elde edildiği çalışma ortamlarında farklı cinsel yönelimlerin kabul edilmesi daha zor olmaktadır. Bu tip mekanlar işçi sınıfına mensup gey erkekler için rahat olmayan, hatta düşmanca tutumların sergilendiği alanlar olabilmektedir (Barrett ve Pollack, 2005: 439). Bütün bunların dışında bir alt-kültür olarak ortaya çıkan gey yaşam tarzının talepleri olan moda, elektronik aletler, ulaşım, eğlence, gezi gibi aktivitelerin ciddi bir maliyeti vardır. Bu tip bir yaşam tarzına sahip olabilmek için sadece yüksek gelir düzeyi değil aynı zamanda çalışma saatlerinin ve günlerinin de esnek olması gerekmektedir. Serbest meslek sahipleri ve beyaz yakalılar bu tip yaşam tarzına daha uygun çalışma düzenine sahipken, yine çalışma saatlerinin daha katı olduğu mavi yakalı iş̧̧i sınıfına mensuplar için böylesi bir yaşam biçimi mümkün olamamaktadır (Barrett ve Pollack, 2005: 439).

$\mathrm{Bu}$ nedenle LGBT hakları için mücadele eden bireyler sinıfsal olarak diğer eşcinsellerden ayrılmaktadırlar. Hareketin temsilcileri ağırlıklı olarak klasik mavi yakalılardan değil beyaz yakalıların içinden çıkmaktadır. LGBT hareketinde yer alan bireyler, kentli, eğitimli, maaşlı meslek sahibi, dünyaya açık, siyasi olarak hayat tarzlarına daha az müdahale etmesi muhtemel sosyal demokrat partilerle sosyalist sol arasında gidip gelen bir kimlik profili çizmektedir. 
ABD ve Avrupa'daki LGBT hareketine kıyasla geç başlayan Türkiye LGBT hareketinin kamuya açılması ve kendini diğer toplumsal hareketler yanında rüştünü ispatlamış bir hareket olarak göstermesi 2013 yılında "Gezi Olayları ile gerçekleşmiştir. Eşcinsel topluluk için buluşma mekanı olarak da sembolik bir anlam içeren İstanbul Taksim'de bulunan Gezi Parkı'na otel ve alışveriş merkezi inşa etmek için belediye ekiplerinin müdahalesiyle başlayan olaylara, çok farklı toplumsal kesimlerden itirazlar gelmiş, protestocuların direnişine kolluk kuvvetleri de sert müdahalelerde bulunmuştur. Bir ayı aşkın süre İstanbul ve Türkiye’nin diğer illerinde geleceğin nitelikli (eğitimli ve beyaz yakalı) iş gücü arzının öğeleri olacak öğrenciler (Boratav, 2013), serbest meslek sahipleri, beyaz yakalı işçiler gibi kentli, orta sınıfa mensup ama özünde "yeni işçi sınıfını” oluşturan bireylerin ve örgütlerin oluşturduğu gruplar kitlesel protesto gösterileri organize etmişlerdir. Gezi Parkı’na fiziksel ve duygusal olarak yakın olan örgütlü ya da örgütsüz LGBT bireyler olayların ilk gününden itibaren toplumsal muhalefetin önemli özneleri olarak parkta ve çevresinde yer almışlardır. Ulusal ve uluslararası medyanın canlı yayınlarla sunduğu olaylar, gökkuşağı renkli bayrak(lar) çevresinde birbirini bulan ve LGBT Blok adı altında oluşan harekete toplumsal muhalefet içinde görünürlük, tanınma ve aşinalık imkanı vermiştir. Gezi Parkı’ndaki LGBT Bloğun ruh halini Bade Okçuoğlu şöyle anlatmaktadır:

"Direnişin ilk günlerinden itibaren, Gezi Parkı’ndaki ağaçlardan birine asılan bir gökkuşağı bayrağı kalabalıkta birbirimizi bulmamızı sağlayan işaret oldu ve LGBT Bloğunun oluşumunu başlattı. Sonraki haftalarda LGBT Bloğu tam teşekküllü revir hizmeti sağlamak ve 24 saat ücretsiz yiyecek-içecek dağıtmak için orada bulundu. LGBT Bloğu afişinin etrafında toplanan gönüllü grupları, film gösterimleri organize ettiler ve yaklaşan Onur Haftası Yürüyüşü için hazırlıklara yardım ettiler. $\mathrm{Bu}$ etkinlikler parktaki günlük yaşamda görünürlüğümüzü sağlamanın önemli araçları oldu ve bu girişimler yeni tanışıklıkların mümkün hale geldiği yollar açtı. Bu özellikle en ayırt edilebilir ve kamusal alandaki görünürlükleri pek de iyi deneyimler getirmeyen trans arkadaşlarımız için geçerliydi. Onların anıları tanınmama, inkar, nefret ve cinayetle doluydu" (Okçuoğlu, 2013).

Gezi Parkı Eylemleri diğer toplumsal dinamiklerin LGBT bireylere bakışında da önemli bir kırılma yaratmıştır. Aktivist Levent Pişkin bu durumu şöyle ifade etmektedir: "LGBT dediğin zaman insanlar 4 tane sessiz harf yan yana geldiği için illegal örgüt zannediyordu Gezi Parkı’ndan evvel” (Tar, 2014). Oysa Gezi süreci ile birlikte LGBT bireyler toplumun “aşağılık” üyeleri değil alanın aktif üyeleri olarak ön plana çıkmışlar; LGBT bireylerle ilk kez bu toplumsal hareket sırasında karşılaşan kimi gruplar, geçmişteki homofobik davranışları nedeniyle onlardan özür diler tavırlar içine girmişlerdir (Okçuoğlu, 2013).

\section{Sonuç yerine}

Yeni toplumsal hareketlerin başlıca özneleri yeni toplumun proleterleşen beyaz yakalı orta sınıfıdır. Bu sınıf, hem eski hareketlerin örgütlü ve görece katı yapılarından ayrılması hem de eski 
toplumsal hareketler içinde kaybolan ya da görmezden gelinen hakları için sistemin yarattığı eski ve yeni dezavantajlarla mücadele eden bir toplumsal tabakayı oluşturmaktadır.

Yeni toplumsal hareketlerden biri olan LGBT hareketi de, kentli, beyaz yakalı, eğitimli orta sınıf LGBT bireyler tarafından inşa edilmektedir. Bir toplumsal hareketin aktif bir parçası olmak, öncelikle kimliğin bu doğrultuda yeniden üretilmesine ve ardından toplumsal alanda ifade edilebilmesine bağhıdır. Bu bağlamda kendini LGBT birey olarak tanımlayan ve kimliğini buna göre kurgulayan bireyler, yeni toplumsal hareketlerin parçası olan diğer hareketler ve onların mensuplarıyla iç içe geçmiş sosyal ağlar kurmakta, yeni toplumsal hareketlerin önemli aktörleri olmaktadırlar.

Kendi içinde cinsel, etnik, sosyal ve ekonomik olarak çok farklı kategorileri olan (erkeksi geyler, efemine geyler, lezbiyenler, biseksüeller, translar, seks işçiliği yapanlar, beyaz yakalı, işsiz, öğrenci gibi) Türkiye'deki LGBT bireyler bugün, tıpkı 1969 yllında Stonewall Ayaklanması̉nda olduğu gibi, toplumda yalnız olmadıklarını, bir araya gelirlerse toplumsal muhalefet içinde ses getirebileceklerini ve politik alana müdahale edebileceklerini görmüşlerdir. Görünürlük sorununu aşan LGBT hareketinin zaman içinde eski toplumsal hareketlere benzer bir şekilde partileşen Yeşiller hareketine mi benzeyeceği yoksa yeni toplumsal hareketlerin ruhuna uygun bir şekilde merkezsiz ve bürokratik kurumlarını oluşturmadan kendilerini destekleyen siyasi oluşumlarla ittifak mı yapacağını önümüzdeki günler gösterecektir. 


\section{Kaynakça}

Adam, B. (1987) The Rise of a Gay and Lesbian Movement, Boston: Twayne Publishers, G. K. Hall \& Co.

Adam, B. (2001) "Globalization and the Mobilization of Gay and Lesbian Communities", P. Hamel, H. Lustiger-Thaler, J. Nederveen Pieterse and S. Roseneil (der.) Globalization and Social Movements içinde, New York: St Martin’s/Palgrave, 166-79.

Altman, D. (1972) Homosexual: Oppression and Liberation, Sydney: Angus and Robertson.

Arrighi, G., T. K. Hopkins ve I. Wallerstein (2004 [1989]) Sistem Karşıtı Hareketler, çev. C. Kanat, B. Somay ve S. Sökmen, İstanbul: Metis Yayınları.

Azizerli, E. (2013) Pink Certificate, BBC belgeseli [çevrimiçi], http://www.bbc.co.uk/programmes/p00q864h [Erişim tarihi: 28.12.2013].

Baba, H. B. (2011) “The Construction of Heteropatriarchal Family and Dissident Sexualities in Turkey”, Fe Dergi, 3(1): 56-64.

Barrett, D. C. ve L. M. Pollack (2005) "Whose Gay Community? Social Class, Sexual Self-Expression, and Gay Community Involvement", The Sociological Quarterly, 46: 437-456.

Bereket, T. ve B. D. Dam (2006) “The Emergence of Gay Identities in Contemporary Turkey”, Sexualities, 9: $131-151$.

Bertram, B. (1995) "New Reflections on the 'Revolutionary' Politics of Ernesto Laclau and Chantal Mouffe," Boundary 2, 22(3): 81-110.

Bildirici, F. (2010) "Eşcinsellik hastalık, tedavi edilmeli”, Hürriyet Pazar [çevrimiçi], 7 Mart, http://www. hurriyet.com.tr/pazar/14031207.asp [Erişim tarihi: 10.01.2014].

Boratav, K. (2013) "Olgunlaşmış Bir Sınıfsal Başkaldırı”, Sendika.org [çevrimiçi],

http://www.sendika.org/2013/06/her-yer-taksim-her-yer-direnis-bu-isci-sinifinin-tarihsel-ozlemi-olansinirsiz-dolaysiz-demokrasi-cagrisidir-korkut-boratav/ [Erişim tarihi: 04.01.2014].

Bourdieu, P. (1998) “L’homme décide, la femme s’efface”, Catherine Portevin ile söyleşi, Télérama, 2532, 22 Temmuz.

Bowman, K. H. (2004) "Attitudes about Homosexuality and Gay Marriage: AEI Studies in Public Opinion", American Enterprise Institute [çevrimiçi], http://www.aei.org/publications/pubID.14882.filter./pub_ detail.asp.

Buechler, M. S. (1995) “New Social Movement Theories”, Sociological Quarterly, 36: 441-464.

Carter, D. (2004) Stonewall: The Riots That Sparked the Gay Revolution, New York: St. Martin's Press.

Castells, M. (2005 [1996]) Enformasyon Çağı: Ekonomi, Toplum ve Kültür, Cilt I, Ağ Toplumunun Yükselişi, çev. E. Kılıç (çev.), İstanbul: İstanbul Bilgi Üniversitesi Yayınları.

Clark, N. T. ve M. S. Lipset (2010) “Toplumsal Sınıflar Ölüyor mu?”, A. Giddens (der.), Sosyoloji Başlangıç Okumaları içinde, çev. G. Aksoy, Ankara: Say Yayınları.

Coşkun, K. M. (2006) "Süreklilik ve Kopuş Teorileri Bağlamında Türkiye’de Eski ve Yeni Toplumsal Hareketler”, SBF Dergisi, 61(1): 67-102.

Connell, R. W. (1998 [1987]) Toplumsal Cinsiyet ve İktidar, çev. C. Soydemir, İstanbul: Ayrıntı Yayınları.

Concil of Europe (2011) Discrimination on grounds of sexual orientation and gender identity in Europe, Strasbourg: Council of Europe Publishing.

D’Emilio J. ve A. Berubeb (1984) “The Military and Lesbians During The McCarthy Years”, Journal of Women in Culture and Society, 9(4): 759-775.

Engindeniz-Şahan, İ. (2012) L’émergence d'un espace public LGBT en Turquie : une analyse de la revue Kaos GL, Yayımlanmamış Doktora Tezi, L'Université de Grenoble, http://www.academia.edu/2323052/ 
Lemergence_dun_espace_public_LGBT_en_Turquie_une_analyse_de_la_revue_Kaos_GL [Erişim tarihi: 02.01.2014].

Ertürk, A. E. (2010) “Kamusal Alanda 'Sapkın İlişki’ Norm Dışı”, Akşam [çevrimiçi], 18 Mart, http://aksam. medyator.com/2010/03/18/haber/guncel/10671/kamusal_alanda_sapkin_iliski_norm_disi.html [Erişim tarihi: 2 Nisan 2010].

Escoffier, J. (1998) American Homo: Community And Pervisty, Berkeley: University of California Press.

Esmer, Y. (2009) Radikalizm, Aşııılık ve Toplumsal Değerler Bir Saha Araştırmasının Bulguları, İstanbul: Uğur Yayınları.

Esmer, Y. (2012) Değişimin Kültürel Sınırları Türkiye Değerler Atlası, İstanbul: Bahçeşehir Üniversitesi Yayınları.

European Commission (2009) Discrimination in the EU in 2009, Special Eurobarometer 317, http:// ec.europa.eu/public_opinion/archives/ebs/ebs_317_en.pdf [Erişim tarihi: 15 Ekim 2013].

European Social Survey, (2005) Exploring Public Attitudes, Informing Public Policy. Selected Findings from the First Three Rounds [çevrimiçi], http://www.europeansocialsurvey.org/docs/findings/ESS1-3_ findings_booklet.pdf [Erişim tarihi: 14 Ekim 2013].

Foucault, M. (2003 [1976, 1984]) Cinselliğin Tarihi, çev. H. U. Tanrı̈over, İstanbul: Ayrıntı Yayınları.

Frankel, B. (1991 [1987]) Sanayi Sonrası Ütopyalar, çev. K. Durand, İstanbul: Ayrıntı Yayınları.

Fulcher, J. ve J. Scott (2011) Sociology, 4. Bask1, Oxford: Oxford University Press.

Giddens, A. (1999 [1981]) İleri Toplumların Sınıf Yapısı, çev. Ö. Baldık, İstanbul: Birey Yayıncılık.

Gouldner, A. (1978a) "New Class Project, 1", Theory and Society, 6(2): 153-203.

Gouldner, A. (1978b) "New Class Project, 11", Theory and Society, 6(3): 343-389.

Güner, U., P. Kalkan, Y. Öz, E. C. Özsoy ve F. Söyle (2011) Türkiye’de Cinsel Yönelim ve Cinsel Ayrımcılı̆̆ın İzlenmesi Raporu 1Ocak-30 Haziran 2010, İstanbul: İstanbul Bilgi Üniversitesi Yayınları.

Gürsu, E. ve S. Elitemiz (2012) 80'lerde Lubunya Olmak, İzmir: Siyah Pembe Üçgen.

Hardt, M. ve A. Negri (2004 [2000]) Çokluk: İmparatorluk Çağında Savaş ve Demokrasi, çev. B. Yıldırım, İstanbul: Ayrıntı Yayınları.

Hocaoğlu, M. (2002) “Eşcinsel Değilim, Sadece Eşcinsellerle Yatıyorum”, V. Ersan (der.) Eşcinsel Erkekler 25 Tanıklık içinde, İstanbul: Metis, 147-149.

Hür, A. (2013) "Elinde Tesbih, Evinde Oğlan, Dudağında Dua...” Radikal, 10 Kasım.

Inglehart, R. ve C. S. Flanagan (1987) "Value Change in Industrial Societies", American Political Science Review, 81(4): 1289-1319.

Inglehart, R. (1990) "Values, Ideology, and Cognitive Mobilization in New Social Movements", R.J. Dalton ve M. Kuechler (der.), Challenging the Political Order: New Social and Political Movements in Western Democracies içinde, New York: Oxford University Press, 43-66.

Jenkins, J. C. ve M. Wallace (1996) “The Generalized Action Potential of Social Movements", Sociological Forum, 11(2): 183-207.

Johnson, K. D. (2004) The Lavender Scare: The Cold War Persecution of Gays and Lesbians in the Federal Government, Chicago: University of Chicago Press.

Kaiser, C. (1998) The Gay Metropolis: The Landmark History of Gay Life in America Since World War II, San Diego: Harcourt Brace \& Company.

KAOS GL (2013) “2013’te Dünyada 238, Türkiye’de 5 Trans Öldürüldü!” [çevrimiçi], http://www.kaosgl. com/sayfa.php?id=15196 [Erişim tarihi: 07.01.2013].

Katz, J. (1976) Gay American History: Lesbians and Gay Men in the U.S.A, Thomas Y. Cromwell Company.

LAMBDA İSTANBUL (2008) İt İti Isırmaz!- İstanbul'da Yaşayan Trans Kadınların Sorunları [çevrimiçi], http://www.lambdaistanbul.org/s/wp-content/uploads/2012/03/Trans_Anket_Kitab1_Grafikli.pdf 
Lash, S. ve J. Urry (1987) The End of Organized Capitalism, Wisconsin: The University of Wisconsin Press. L’Encyclopédie du XXé Siècle (1993) Cilt: Les années soixante, Paris: France Loisir, 102.

Macionis, J. J. (2012) Sosyoloji, çev. V. Akan, İstanbul: Nobel Yayıncilık.

Marsh, A. (1975) “The Silent Revolution, Value Priorities, and the Quality of Life in Britain", American Political Science Review, 69: 1-30.

McAdam, D., J. D. McCarty, ve M. N. Zald (1988) “Social Movements,", Neil Smelser (der.), Handbook of Sociology içinde, Beverly Hills, CA: Sage, 695-737.

Mieli, M. (1980) Homosexuality and Liberation: Elements of a Gay Critique, London: Gay Men's Press.

Murray, S. O. (2000) Homosexualities, Chicago: University of Chicago Press.

Offe, C. (1985) "New Social Movements: Challenging the Boundaries of Institutional Politics", Social Research, 52(4): 817-868.

Offe, C. (1987) “Challenging the Boundaries of Institutional Politics: Social Movements since the 1960's", C.S. Marler (der.), Changing Boundaries of the Political içinde, Cambridge: Cambridge University Press, 63-106.

Okçuoğlu, B. (2013) “The LGBT Block”, Rethinking Gezi Through Feminist and LGBT Perspectives”, Jadaliyya Reports [çevrimiçi], 11 Kasım, http://www.jadaliyya.com/pages/index/15037/rethinkinggezi-through-feminist-and-lgbt-perspect [Erişim tarihi: 03.01.2014].

Öz, Y. (2009) ““'Ahlaksızlar”ın Mekansal Dışlanması”, KAOS GL [çevrimiçi], 28 Mayıs, http://www.kaosgl. com/sayfa.php?id=2949\#_ftn3 [Erişim tarihi: 10.01.2014].

Özbay, C. (2011) "Neoliberal Erkekliğin Sosyolojisine Doğru: Rent Boylar Örneği”, C. Özbay, A. Terzioglu ve Y. Yasin, Yeşim (der.), Neoliberalizm ve Mahremiyet: Türkiye’de Beden, Sağlık, Cinsellik içinde, İstanbul: Metis, 179-208.

Öztek, A. (2007) “Türk Sinemasında Eşcinsellik”, Kaos GL, 52.

Pakulski, J. (1993) “The Dying of Class or Marxist Class Theory?”, International Sociology, 8(3): 279-292.

Pakulski, J. (1993). "Mass Social Movements and Social Class", International Sociology, 8(2): 131-158.

Parkin, F. (1968) Middle Class Radicalism, New York: Praeger.

Perinçek, D. (2000) Eşcinsellik ve Yabancılaşma, İstanbul: Kaynak Yayınları.

Rohrschneider, R. (1990) “The Roots of Public Opinion Toward New Social Mavements: An Emprical Test of Competing Explanations”, American Journal of Political Science, 34(1): 1-30.

Rose, F. (1997) “Toward a Class-Cultural Theory of Social Movements: Reinterpreting New Social Movements”, Sociological Forum, 12(3): 461-494.

Selek, P. (2001) Maskeler, Süvariler, Gacılar: Ülker Sokak - Bir Alt Kültürün Dışlanma Mekânı, İstanbul: Aykırı.

Tapınç, H. (1992) “Masculinity, Femininity and Turkish Male Homosexuality”, Ken Plummer (der.) Modern Homosexualities içinde, London: Routledge, 39-49.

Tar, Y. (2013) Yoldaş Ben İbneyim: Solun LGBT ile İmtihanı, İstanbul: Ceylan Yayınları.

Tar, Y. (2014) “İbne Gezi Parkı’nda Çarka Çıkan Lubunya Demek”, Levent Pişkin ile Söyleşi, Kaos GL, 11 Ocak.

TİSK (2012) “2012 TÜİK HIA Verilerinin Degerlendirilmesi”, İsgücü Piyasası Bülteni [çevrimiçi], 19, http:// www.tisk.org.tr/download/shb/3354.pdf [Erişim Tarihi: 03.09.2012].

Toffler, A. (1981 [1980]) Üçüncü Dalga, çev. A. Seden, İstanbul: Altın Kitaplar Yayınevi.

Uysal, Ü. E. (2006) “Soylulaştırma Kuramlarının İstanbul'da Uygulanabilirliği: Cihangir Örneği”, Planlama, 6(2): 79.

Wallerstein, I. ve E. Balibar (1993 [1991]) Irk, Ulus, Sınıf, İstanbul: Metis Yayınları.

Williams, R. (1989 [1983]) 2000’e Doğru, İstanbul: Ayrıntı Yayınları. 